\title{
Rhegmatogenous retinal detachment in Wyburn-Mason syndrome: case report
}

\author{
Descolamento regmatogênico de retina na síndrome de \\ Wyburn-Mason: relato de caso
}

\author{
Flávio MacCord Medina ${ }^{1}$ \\ Otacílio de Oliveira Maia Júnior ${ }^{2}$ \\ Walter Yukihiko Takahashi ${ }^{3}$
}

Study carried out at the Retina and Vitreous Service, Universidade de São Paulo - USP - São Paulo (SP) Brazil.

'Vitreoretinal Specialist at the Department of Ophthalmology, Universidade do Estado do Rio de Janeiro UERJ - Rio de Janeiro (RJ) - Brazil.

${ }^{2}$ Vitreoretinal Specialist at the Department of Ophthalmology, São Rafael Hospital, Monte Tabor Foundation Salvador (BA) - Brazil.

${ }^{3}$ Head of the Vitreoretinal Service, Department of Ophthalmology - USP - São Paulo (SP) - Brazil.

Correspondence address: Flávio MacCord. Rua João Borges, 204 - Rio de Janeiro (RJ) CEP 22451-100

E-mail: fmaccord@hotmail.com

Recebido para publicação em 02.03.2009

Última versão recebida em 09.08.2009

Aprovação em 21.09.2009

Nota Editorial: Depois de concluída a análise do artigo sob sigilo editorial e com a anuência dos Drs. Ayrton Roberto Branco Ramos e João Carlos Miranda Gonçalves sobre a divulgação de seus nomes como revisores, agradecemos sua participação neste processo.

\begin{tabular}{|l|}
\hline ABSTRACT \\
\hline Wyburn-Mason is a rare vascular disorder, comprised of arteriovenous \\
malformations (AVMs) of the midbrain and retina. It can cause visual \\
symptoms depending on its localization and extension. Vitreous and \\
intraretinal hemorrhage and neovascular glaucoma have been previously \\
described. A case of rhegmatogenous retinal detachment in a patient \\
with Wyburn-Mason syndrome is described. A 27 year-old woman \\
previously diagnosed with Wyburn-Mason syndrome, sought attendance \\
with sudden low vision in right eye 3 months before. She presented \\
moderate vitreous hemorrhage and retinal detachment with a superior tear. \\
She underwent a successful posterior vitrectomy with implantation of \\
silicone oil, with reattachment of the retina. Rhegmatogenous retinal de- \\
tachment in a patient with Wyburn-Mason syndrome has been not pre- \\
viously described in the literature. Vitrectomy in this case present chal- \\
lenges related to intraoperatory bleeding risk, to a posterior pole tearamong \\
AVMs and the difficulty of obtaining free retina for photocoagulation. \\
\hline
\end{tabular}

Keywords: Arteriovenous malformations/complications; Arteriovenous malformations/diagnosis; Retinal detachment/etiology; Vitreous hemorrhage/etiology; Intracranial arteriovenous malformations/complications; Intracranial arteriovenous malformations/diagnosis; Retinal artery/abnormalities; Retinal vein/abnormalities; Syndrome; Case reports

\section{INTRODUCTION}

Wyburn-Mason syndrome (WMS), also known as the Bonnet-Dechaume-Blanc syndrome, is a rare phakomatosis characterized by congenital ipsilateral retinal, brain (usually midbrain), and, less frequently, facial angiomas $^{(1)}$. It is a congenital, nonhereditary condition, without gender or race predilection. Bonnet et al. first noted the combination of retinal and intracranial AVMs in $1937^{(2)}$, but the eponym derives from the more comprehensive report of Wyburn-Mason of 27 cases with retinal AVMs, 22 of whom also had intracranial $\mathrm{AVMs}^{(3)}$. The condition results from a disturbance in the embryologic development of the vascular mesoderm ${ }^{(4)}$. AVM or racemose hemangioma consists of a markedly dilated and tortuous arteriole contiguous with a similar vein involving the optic disc and retina ${ }^{(5)}$. They usually remain stable and fluorescein angiography typically shows a rapid transit of dye through the lesion without leakage ${ }^{(6)}$.

\section{CASE REPORT}

A 27-year-old woman sought attendance with sudden low vision in right eye 5 months before. She referred low vision in this eye since child- 
hood and brought a fundus photograph showing enormously dilated vascular loops and fluorescein angiogram exam done 1 year before showing rapid transit of dye through the lesion without leakage (Figure 1).
Visual acuity was counting fingers at 2 meters in the right eye and 20/20 in the left eye. Both eyes were emmetropes and presented no anterior segment abnormalities. Right eye presented moderate vitreous hemorrhage and retinal detachment

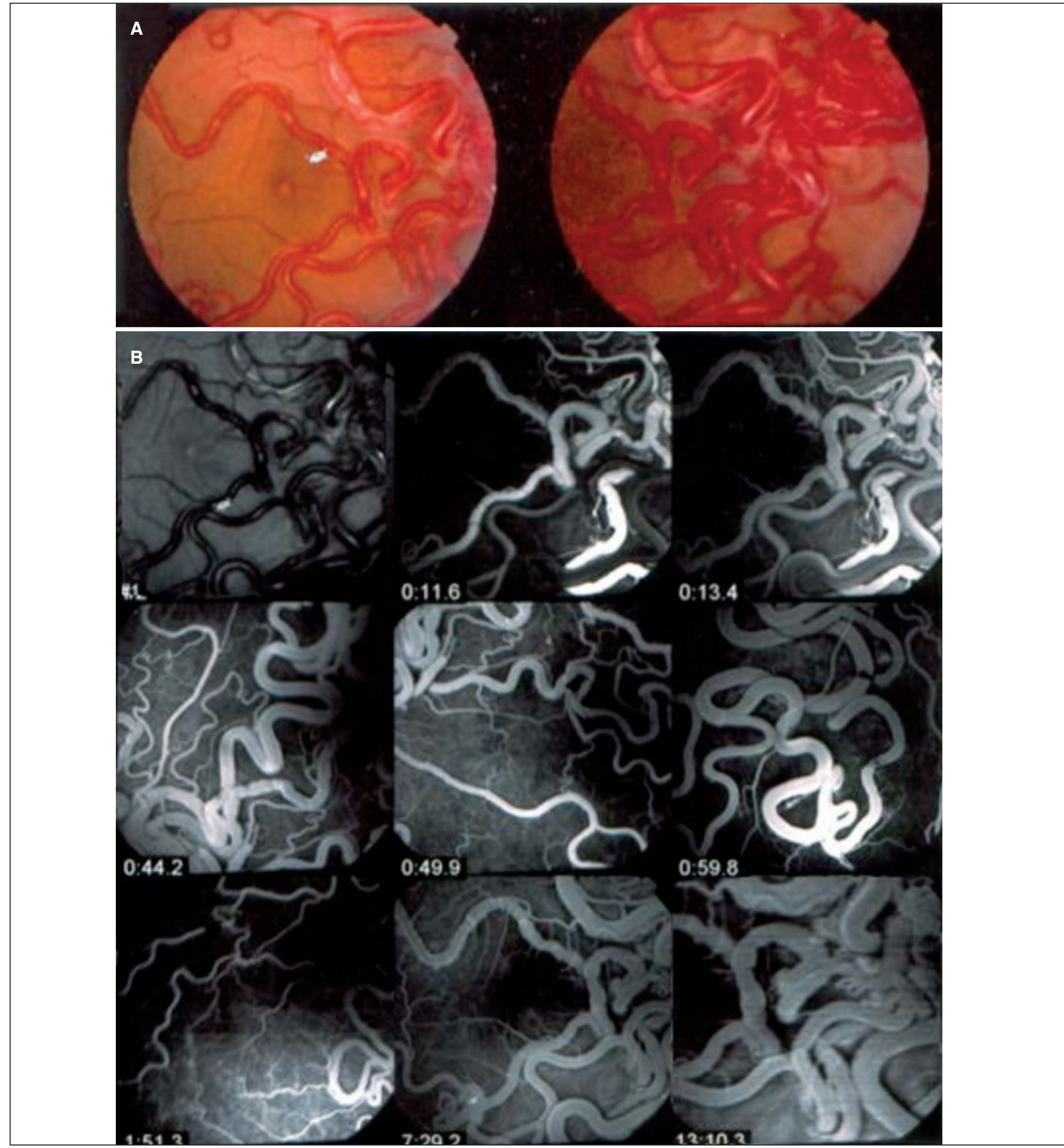

Figure 1 - Fundus photograph (A) showing enormously dilated vascular loops and fluorescein angiogram exam (B) done 1 year before showing rapid transit of dye through the lesion without leakage 
with a small peripheral superior tear and left eye fundus was normal.

She underwent a successful 23-gauge posterior vitrectomy. A posterior pole hole was found during the procedure and air-fluid exchange was performed with no use of perfluorcarbon and subretinal fluid was passively drained through the holes, followed by endophotocoagulation and silicone oil implantation through one sclerotomy converted to 20 -gauge (Figure 2).

In 3-month follow-up, the retina remains attached, and visual acuity is $20 / 200$.

\section{DISCUSSION}

AVMs are usually considered to be stable retinal lesions. Low vision in Wyburn-Mason syndrome is usually due to AVMs of anterior visual pathway ${ }^{(7)}$. Previously described complications of retina AVMs include intraretinal macular hemorrhage, central and peripheral retinal vein occlusions, neovascular glaucoma, and vitreous hemorrhage ${ }^{(8)}$.

Such complications are related to high blood flow due to direct connection of the major vessels without capillary interposition. The veins are exposed to arterial blood pressures due to the lack of capillaries. Turbulent blood flow and vessel wall damage may result, which can lead to thrombosis and vessel occlusion ${ }^{(5)}$.

Our patient presented large retinal vascular AVMs of most parts in the fundus with enormously dilated vascular loops, previously described as "bag of worms". The veins were so severely engorged and tortuous that the disk was almost completely obscured. It has been noted in postmortem observations that these vessels in the posterior segment touch at
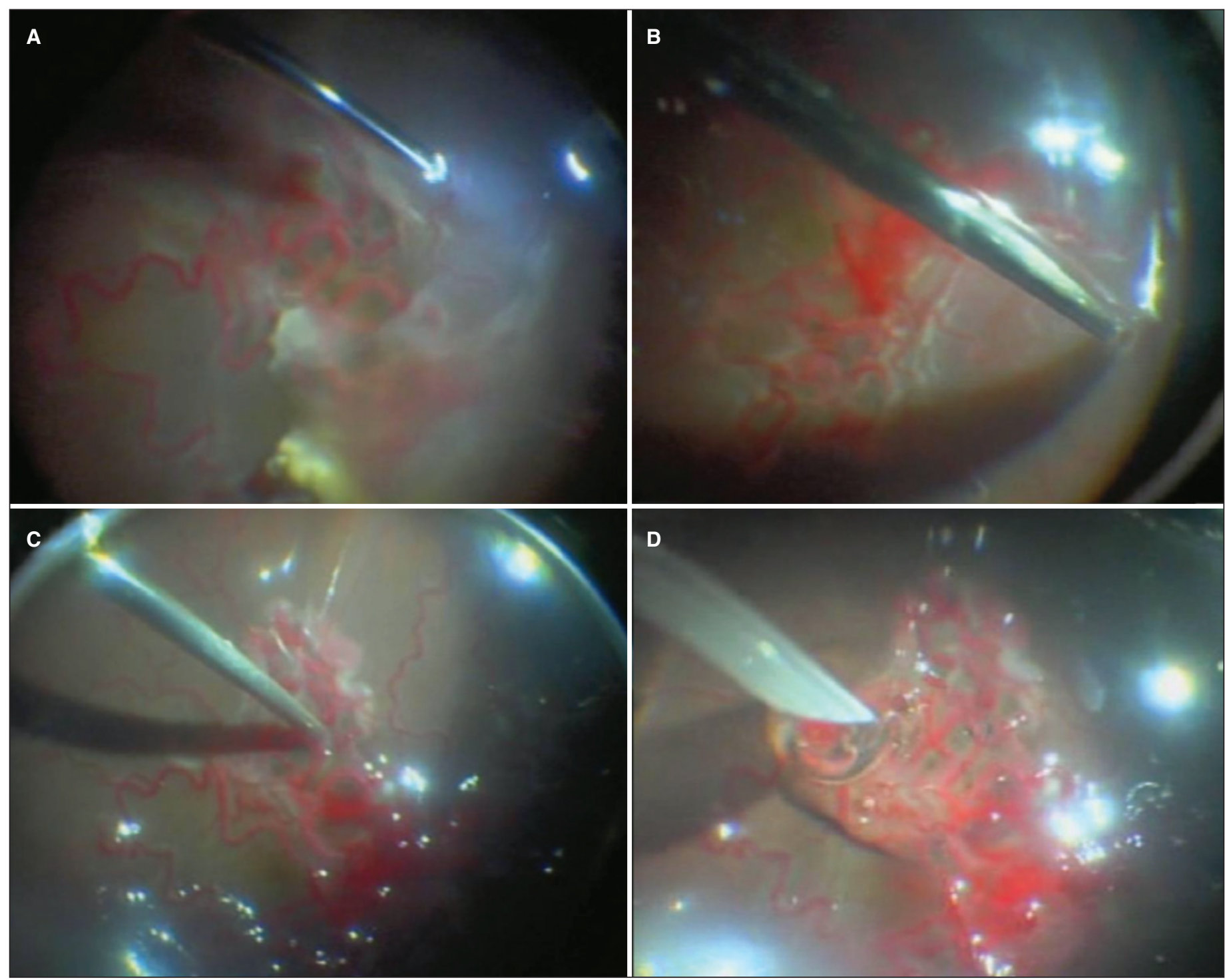

Figure 2 - Intraoperatory images, showing vitreous hemorrhage removal (A), air fluid exchange and passive endodrenage through peripheral hole (B) and posterior pole hole (C) and silicone oil implant (D) 
points the pigment epithelium or the choroid's lamina vitrea and conversely, protrude far into the vitreous cavity ${ }^{(9)}$.

The hypothesis to the relationship between retinal AVMs and retinal detachment development in our case are:

- Increased retinal venous pressure, increased turbulence of blood flow, decreased retinal arterial pressure and, finally, decreased perfusion of adjacent retinal tissues are probably related to AVMs blood flow ${ }^{(8)}$. The consequent retinal ischemia may have lead to retinal holes formation.

- The first event would have been vitreous hemorrhage, as previously described in the literature, and the longstanding hemorrhage contracted and caused the holes.

Vitrectomy in this case presented some challenges. Intraoperatory bleeding risk was prevented with low aspiration rates and careful detachment of posterior hyaloid. In case of bleeding, it should be promptly controlled with increase of the vented gas forced infusion (VGFI) pressure and endodiathermy. Perfluorcarbon could not be used because of difficulty of visualization of optic nerve head to its removal and posterior pole hole. The hole among AVMs caused difficulty of obtaining free retina for photocoagulation, which lead to the need of using silicone oil as intraocular tamponade.

\section{RESUMO}

A síndrome de Wyburn-Mason é uma desordem vascular rara, caracterizada por malformações arteriovenosas (MAV) do mesencéfalo e retina. Pode causar sintomas visuais por sua localização e extensão. Hemorragia vítrea, intrarretiniana e glaucoma neovascular já foram descritos. Descreve-se um caso de descolamento regmatogênico de retina em uma paciente com síndrome de Wyburn-Mason. Uma paciente feminina de 27 anos com diagnóstico prévio de síndrome de Wyburn-Mason procurou atendimento com queixa de baixa acuidade visual súbita no olho direito há três meses. Apresentava hemorragia vítrea moderada e descolamento de retina com rotura superior. Foi submetida a vitrectomia posterior com implante intravítreo de óleo de silicone, com reaplicação da retina. Descolamento regmatogênico de retina em paciente com síndrome de Wyburn-Mason não havia sido previamente descrito na literatura. A vitrectomia nesse caso apresentou dificuldades relacionadas ao risco de sangramento intraoperatório, à presença de rotura no polo posterior entre as MAVs e à dificuldade de obtenção de retina livre para fotocoagulação.

Descritores: Malformações arteriovenosas/complicações; Malformações arteriovenosas/diagnóstico; Descolamento retiniano/etiologia; Hemorragia vítrea/etiologia; Malformações arteriovenosas intracranianas/complicações; Malformações arteriovenosas intracranianas/diagnóstico; Artéria retiniana/anormalidades; Veia retiniana/anormalidades; Síndrome; Relatos de casos

\section{REFERENCES}

1. Reck, SD, Zacks DN, Eibschitz-Tsimho M. Retinal and Intracranial Arteriovenous Malformations: Wyburn-Mason Syndrome. J Neuroophthalmol. 2005; 25(3):205-8

2. Bonnet P, Dechaume J, Blanc E. L'anévrysme cirsoïde de la rétine (anévrysme recémeux): ses relations avec l'anéurysme cirsoïde de la face et avec l'anévrysme cirsoïde du cerveau. J Med Lyon. 1937;18:165-78.

3. Wyburn-Mason R. Arteriovenous aneurysm of mid-brain and retina, facial naevi, and mental changes. Brain. 1943;66:163-203.

4. Selhorst JB. Phacomatoses. In: Miller NR, Newman NJ, editors. Walsh and Hoyt clinical neuro-ophthalmology. $5^{\text {th }}$ ed. Baltimore: Williams \& Wilkins; 1998. p.2725-9.

5. Brown GC. Congenital retinal arteriovenous communications (racemose hemangiomas). In: Guyer DR, Yannuzzi LA, Chang S, Shields JA, Green R, editors. Retina-vitreous-macula. Philadelphia: WB Saunders; 1999. p.1172-4.

6. Schmidt D, Pache M, Schumacher M. The congenital unilateral retinocephalic vascular malformation syndrome (Bonnet-Dechaume-Blanc syndrome or Wyburn-Mason syndrome): review of the literature. Surv Ophthalmol. 2008;53(3): 227-49. Erratum in: Surv Ophthalmol. 2009;54(1):165.

7. Dayani PN, Sadun AA. A case report of Wyburn-Mason syndrome and review of the literature. Neuroradiology. 2007; 49(5):445-56. Review.

8. Mansour AM, Wells CG, Jampol LM, Kalina RE. Ocular complications of arteriovenous communications of the retina. Arch Ophthalmol. 1989;107(2): 232-6

9. Krug EF, Samuels B. Venous angioma of the retina, optic nerve, chiasm and brain. A case report with postmortem observations, Arch Ophthalmol. 1932;8: $871-9$.

Ao enviar um artigo para publicação, 